\title{
Tawazaun
}

Jurnal Pendidikan Islam

http://ejournal.uika-bogor.ac.id/index.php/TAWAZUN/index

Vol. 13, No. 2, 2020, e-ISSN: 2654-5845, hlm. 124-141, DOI: 10.32832/tawazun.v13i2.3221

\section{Pengembangan Materi Ajar Kimia Berbasis Nilai Keimanan}

\author{
Bahrum Subagiya ${ }^{1 *}$, Wido Supraha ${ }^{2}$ \\ 1\&2Universitas Ibn Khaldun Bogor, Indonesia \\ *bahrum.subagiya@uika-bogor.ac.id
}

\begin{abstract}
The government has mandated that the purpose of national education is to develop the potential of students to become faithful and righteous human beings. However, the facts in the field show that the teaching materials are still far from the value of faith and piety. This study tries to implement the values of faith in the XII grade Chemistry textbook. The method used is the method of developing Islamic textbooks based on faith values. The results of this study, namely, the application of the value of faith in the XII Chemistry textbook can be done in the following steps: first, providing an introduction containing Islamic advice. Second, insert an expression of God's omnipotence. Third, to reveal the wisdom of natural creation that fosters gratitude. Fourth, correcting concepts that are contrary to Islamic teachings. Fifth, include relevant Al-Qur'an verses or hadiths. Sixth, enter information on the progress of Muslim scientists and finally link the material with the application of Islamic teachings.
\end{abstract}

Keywords: teaching materials; chemistry; faith

\section{Abstrak}

Pemerintah telah mengamanahkan bahwa tujuan dari pendidikan nasional untuk berkembangnya potensi peserta didik agar menjadi manusia yang beriman dan bertakwa. Namun, fakta di lapangan menunjukan bahwa materi-materi ajar masih jauh dari nilai keimanan dan ketakwaan. Penelitian ini mencoba untuk mengimplementasikan nilai-nilai keimanan pada buku ajar Kimia kelas XII. Metode yang digunakan adalah metode pengembangan buku ajar islami berbasis nilai keimanan. Hasil dari penelitian ini yaitu, penerapan nilai keimanan pada buku teks Kimia XII dapat dilakukan dengan langkah-langkah sebagai berikut: pertama, memberikan pengantar yang berisikan nasihatnasihat Islam. Kedua, menyisipkan ungkapan kemahakuasaan Allah. Ketiga, mengungkapkan hikmah penciptaan alam yang menumbuhkan syukur. Keempat, mengoreksi konsep yang bertentangan dengan ajaran Islam. Kelima, memasukkan ayat Al-Qur'an atau hadits yang relevan. Keenam, memasukkan informasi kiprah ilmuwan muslim dan terakhir mengaitkan materi dengan penerapan ajaran Islam.

Kata kunci: materi ajar; kimia; keimanan

Article Information: Received November 19, 2020, Accepted November 30, 2020, Published December 29, 2020 Published by: Program Studi Magister Pendidikan Agama Islam Universitas Ibn Khaldun Bogor How to cite: Subagiya, B., \& Supraha, W. (2020). Pengembangan Materi Ajar Kimia Berbasis Nilai Keimanan. Tawazun: Jurnal Pendidikan Islam, 13(2). doi: 10.32832/tawazun.v13i2.3654 


\section{Pendahuluan}

Allah telah menciptakan alam ini tanpa sia-sia. Ada maksud dan tujuan alam ini diciptakan, yaitu untuk kemaslahatan makhluk-makhluk-Nya, sebagai sarana beribadah kepada-Nya dan sekaligus sebagai bukti tentang keesaan-Nya (Fauzan, 2016). Alam semesta merupakan tandatanda atau petunjuk bagi sang maha pencipta, Allah. Dengan melihat tanda-tanda tersebut orang yang berakal, orang yang memikirkan penciptaan alam ini, akan mendapatkan kebesaran Allah. Sehingga, akan bertambahlah keimanan orang tersebut.

Dalam pelajaran sains di sekolah-sekolah, para murid seharusnya didorong untuk memikirkan penciptaan alam ini, sehingga mereka bisa merasakan kekuasaan dan kebesaran Allah, Tuhan Maha Pencipta. Dengan demikian juga, para murid mendapatkan bertambahnya keimanan dan ketakwaan. Hal ini pun didukung oleh pemerintah, bahwasanya pemerintah mengusahakan dan menyelenggarakan satu sistem pendidikan nasional, yang meningkatkan keimanan dan ketakwaan. Selain itu, pendidikan nasional berfungsi mengembangkan kemampuan dan potensi peserta didik agar menjadi manusia yang beriman dan bertakwa kepada Tuhan Yang Maha Esa.

Akan tetapi fakta di lapangan berbeda jauh dengan tujuan dan cita-cita yang terkandung dalam Undang-Undang Dasar (UUD) 45, pasal 31, ayat 3 dan Undang-Undang nomor 20, tahun 2003, pasal 3. Sebagai contoh dari sekian banyak buku yang diterbitkan pemerintah melalui program buku Sekolah Elektronik (BSE) yaitu pada buku Panduan Pembelajaran Kimia XII Untuk SMA \&MA karya Suwardi, dkk. Dalam buku tersebut, banyak kekurangan dalam konten/isi. Di dalam pengajaran buku tersebut terlihat tidak mengaitkan sama sekali dengan kekuasaan dan kebesaran Allah, Sang Maha Pencipta, serta banyak menyembunyikan faktafakta kunci sejarah. Pengajarannya hanya menerapkan pola yang bersifat sangat teknis dan berorientasi nilai akademik.

Buku ajar yang digunakan oleh pemerintah masih mengacu kepada buku-buku yang diterbitkan oleh Barat. Hal ini dapat diketahui dari sumber-sumber yang dipakai sebagai acuan dalam penyusunan buku tersebut. Penulis telah meninjau beberapa buku ajar Kimia kelas XII dan didapati buku-buku yang menjadi acuan penulisan di dominasi oleh buku-buku terbitan dari Barat. Buku-buku yang ditulis dan diterbitkan oleh Barat harus diwaspadai karena mengandung banyak problem. Di mana ilmu-ilmu yang berkembang di Barat telah mengalami sekularisasi dan westernisasi (Armas \& Kania, 2013). Nilai-nilai yang terkandung dalam buku ajar Kimia XII masih banyak mengandung unsur sekularisasi dan westernisasi, sehingga perlu adanya usaha Islamisasi pada buku ajar tersebut.

Tujuan dari penelitian ini adalah mengimplementasikan nilai-nilai keimanan pada buku ajar, khususnya pada buku ajar Kimia kelas XII A. Adapun manfaat penelitian ini yaitu untuk menghasilkan materi ajar yang Islami, syarat dengan muatan keimanan.

\section{Metodologi Penelitian}

Penelitian ini merupakan penelitian pengembangan materi ajar sains yang berbasis pada nilai keimanan yang dikembangkan oleh Wendi Zarman, yaitu: memberikan pengantar yang berisikan nasihat-nasihat Islami, menyisipkan ungkapan kemahakuasaan Allah, mengungkapkan hikmah penciptaan alam yang menumbuhkan syukur, mengoreksi konsep yang bertentangan dengan ajaran Islam, memasukkan ayat Al-Qur'an atau hadits yang relevan, dan mengaitkan materi dengan penerapan ajaran Islam (Zarman, 2012). Sementara Wido Supraha menambahkan satu teori yang penting yaitu, memasukkan informasi kiprah ilmuwan muslim (Supraha, 2018).

Adapun langkah-langkah yang penulis lakukan yaitu dengan: mengumpulkan beberapa buku ajar Kimia yang digunakan di SMA Islam, mengumpulkan kekeliruan dan kekurangan 
fakta ajar, menyusun sejarah tentang kimia dan filsafat pelajaran kimia, menyiapkan filosofi perkembangan sains kimia di masa peradaban Islam, menyiapkan konten fakta sesungguhnya dalam sejarah peradaban Islam, lalu mengaitkan ayat-ayat Al-Qur'an dan hadits-hadits Nabawi yang berkaitan dengan sains kimia, dan mencari tokoh-tokoh sarjana muslim terkait sains kimia.

Ada tiga materi yang akan penulis teliti dalam buku Panduan Pembelajaran Kimia XII Untuk $S M A \& M A$. Bab pertama yaitu sifat-sifat koligatif larutan yang meliputi: cara menyatakan konsentrasi, sifat koligatif larutan nonelektrolit, dan sifat koligatif larutan elektrolit. Bab kedua menjelaskan reaksi redoks dan elektro Kimia yang meliputi: reaksi oksidasi dan reduksi, sel elektrokimia, dan korosi logam. Bab ketiga mengenai kelimpahan unsur di alam dan identitasnya yang meliputi: unsur-unsur golongan utama, unsur-unsur transisi, dan unsurunsur radioaktif (Suwardi \& Widiasih, 2009).

Begitu juga dengan buku Kimia 3: Untuk. SMA/MA Kelas XII yang disusun oleh Ari Harnanto dan Ruminten yang memuat: Bab pertama sifat koligatif larutan: sifat koligatif larutan dan perbandingan sifat koligatif larutan elektrolit dan nonelektrolit. Bab kedua meliputi: reaksi redoks dan elektrokimia: persamaan reaksi redoks, reaksi redoks dalam sel elektrokimia, potensial sel, reaksi redoks ditinjau dari harga potensial sel, korosi, dan elektrolisis. Bab ketiga mengenai Kimia unsur yang meliputi: unsur-unsur di alam, sifat-sifat unsur, manfaat unsur dan senyawanya, penetapan kadar zat dalam senyawa, dan unsur radioaktif (Harnanto \& Ruminten, 2009).

Setelah data yang diperlukan terkumpul, penulis mencoba menerapkan pola pengembangan materi ajar berbasis pada nilai keimanan yang telah dikembangkan oleh Wendi Zarman dan Wido Supraha.

\section{Hasil dan Pembahasan}

\section{A. Teori Islamisasi}

Penelitian mengenai Islamisasi bukanlah hal baru di tahun-tahun sekarang. Ada banyak tokoh yang telah meneliti, merumuskan, mengonsep, mengembangkan, dan mensosialisasikannya ke masyarakat luas. Syed Muhammad Naquib Al-Attas merupakan salah satu sosok penggagas Islamisasi ilmu. Ia telah menulis buku yang berjudul Preliminary Statement on a General Theory of The Islamizations of The Malay-Indonesian Archipelago. Pada buku ini ia mengkritisi sekularisasi ilmu pengetahuan yang terjadi di dunia barat dan lewat buku ini, ia gagaskan Islamisasi ilmu. Selanjutnya pada tahun 1973, Al-Attas menyusun Risalab untuk Kaum Muslimin yang terkandung di dalamnya peringatan akan bahaya sekularisasi dan perlunya Islamisasi sebagai sebuah solusi (Husaini \& al, 2013).

Tidak hanya menulis buku-buku, Al-Attas juga menyampaikan ide islamisasinya dalam konferensi Internasional di hadapan tokoh-tokoh pendidikan dunia Muslim di Mekkah tahun 1977. Di dalam konferensi tersebut ia menyampaikan tantangan terbesar yang dihadapi oleh kaum muslimin adalah sekularisasi ilmu pengetahuan. Ia menggulirkan gagasan Islamisasi ilmu pengetahuan sebagai solusinya. Setahun setelah itu, ia menulis buku Islam and Secularism, untuk mempertajam gagasannya. Di tahun 1980, ia menulis kembali sebuah buku berjudul The Concept of Educations in Islam, yang kemudian ide-idenya mengenai Islam ilmu pengetahuan dikumpulkan dan dibukukan dengan judul Prolegomena to the Metaphysis of Islam (Husaini \& al, 2013)..

Tokoh lain yang terkenal dengan ide Islamisasi ilmu pengetahuan adalah Ismail Raji alFaruqi. Ide Islamisasi yang dicetuskan oleh al-Faruqi sejatinya transpirasi dari ide al-Attas. Karya termasyhur yang telah ditulisnya yaitu Islamization of Knowledge: General Principles and Workplan, yang telah diterjemahkan ke dalam bahasa Indonesia dengan judul Islamisasi 
Pengetabuan. Ia menjelaskan pengertian Islamisasi ilmu sebagai usaha dalam memberikan definisi baru, mengatur data-data, memikirkan lagi jalan pemikiran dan menghubungkan data-data, mengevaluasi kembali kesimpulan-kesimpulan, memproyeksikan kembali tujuantujuan dan melakukan semua itu sedemikian rupa sehingga disiplin-disiplin itu memperkaya wawasan Islam dan bermanfaat bagi cause (cita-cita) Islam (al-Faruqi, 1984).

Berapa tokoh yang menggagas Islamisasi yang terkenal dan memberikan pengaruh di antaranya Seyyed Hossein Nasr, Ja'far Syekh Idris, Thaha Jabir al-Alwani, Ibrahim Raghab, Osman Bakar, dan Ziauddin Sardar (Husaini \& al, 2013). Pemikiran Islamisasi beberapa tokoh di atas akan penulis jelaskan dalam bab berikutnya. Sedangkan penelusuran hasil penelitian mengenai Islamisasi di Indonesia ada beberapa karya yang penulis dapatkan, yaitu: Islamisasi Sains dan Kampus karya AM. Saefuddin, Pengantar Islamisasi Ilmu Pengetahuan dan Sejarah karya Imaduddin Khalil, Islamisasi Sains: Sebuab Upaya Mengislamkan Sains Barat Modern karya Budi Handrianto, dan sebuah disertasi dengan judul Studi Pengembangan Buku Teks Ilmu Pengetahuan Alam Sekolah Menengah Pertama Berbasis Nilai Keimanan karya Wendi Zarman.

Judul buku terakhir di atas yang menjadi acuan penulis sebagai landasan dasar analisa buku ajar Kimia XII. Wendi menggagas langkah-langkah islamisasi dalam buku ajar ke dalam tujuh langkah, yaitu: Memberikan pengantar yang berisikan nasihat-nasihat Islami, menyisipkan ungkapan kemahakuasaan Allah, mengungkapkan hikmah penciptaan alam yang menumbuhkan syukur, mengoreksi konsep yang bertentangan dengan ajaran Islam, memasukkan ayat al-Qur'an atau hadits yang relevan, memasukkan informasi kiprah ilmuwan muslim dan mengaitkan materi dengan penerapan ajaran Islam (Zarman, 2012)

\section{B. Buku Teks Kimia Kelas XII A}

Muslich mendefinisikan buku teks sebagai buku yang berisi uraian bahan tentang mata pelajaran atau bidang studi tertentu, yang disusun secara sistematis dan telah diseleksi berdasarkan tujuan tertentu, orientasi pembelajaran, dan perkembangan siswa, untuk diasimilasikan (Muslich, 2016). Sedangkan Tarigan, berdasarkan definisi yang dikemukakan oleh Hall Quest, Lange, Bacon, dan Buckingham, mendefinisikan buku teks sebagai buku pelajaran dalam bidang studi tertentu yang merupakan buku standar, yang disusun oleh pakar dalam bidang itu untuk maksud-maksud dan tujuan-tujuan instruksional, yang diperlengkapi dengan sarana-sarana pengajaran yang serasi dan mudah dipahami oleh para pemakainya di sekolah-sekolah dan perguruan tinggi sehingga dapat menunjang suatu program pengajaran (Zarman, 2012).

Adapun buku teks Kimia kelas XII yang penulis jadikan acuan untuk dianalisis dan Insya Allah akan dibuatkan panduannya untuk usaha Islamisasi yaitu buku-buku paket Kimia yang diterbitkan pemerintah, dalam hal ini Departemen Pendidikan Nasional, berupa buku sekolah elektronik yang dapat dengan mudah diunduh lewat laman http://bse.depdiknas.go.id. Ada lima buku yang penulis ambil yaitu: Suwardi, Soebiyanto, dan Th. Eka Widiasih, Panduan Pembelajaran Kimia XII; Ari Harnanto dan Ruminten, Kimia 3: Untuk SMA/MA Kelas XII; Iman Rahayu, Praktis Belajar Kimia untuk Kelas XII; Elisabeth Deta Lustiyati, Aktif Belajar Kimia: untuk SMA dan MA Kelas XII; Teguh Pangajuanto dan Tri Rahmidi, Kimia 3: Untuk SMA/MA kelas XII

Kelima buku tersebut diterbitkan oleh Departemen Pendidikan Nasional, dan dari kelima buku teks tersebut, penulis hanya mengambil setengah bagian awal (semester pertama) yang akan dikaji lebih mendalam. Ada tiga bab yang dibahas di setiap masing-masing buku yaitu (1) Sifat koligatif larutan yang meliputi: sifat koligatif larutan dan perbandingan sifat koligatif larutan elektrolit dan nonelektrolit. (2) Reaksi redoks dan elektro Kimia yang meliputi: persamaan reaksi redoks, reaksi redoks dalam sel elektro Kimia, potensial sel, reaksi redoks ditinjau dari harga potensial sel, korosi, dan elektrolisis. (3) Kimia unsur yang 
meliputi: unsur-unsur di alam, sifat-sifat unsur, manfaat unsur dan senyawanya, penetapan kadar zat dalam senyawa, dan unsur radioaktif.

\section{Sejarah Kimia}

Pengajaran kimia harus diawali dari sejarah terhadap nama cabang sains tersebut. Muhammad al-Khwarizmi menegaskan bahwa al-Kimiya adalah istilah dari bahasa Arab. Istilah kimia pertama kali adalah asli dari Mesir menggunakan kata khemeia, yang kemudian dalam bahasa Arab berubah menjadi al-kimiya. Kata terakhir ini yang kemudian diadopsi oleh bangsa Eropa menjadi alchemy, dan para pekerja di bidang tersebut disebut dengan alchemists. Istilah alchemy diaplikasikan dalam keseluruhan sejarah kimia dalam rentang hampir dua ribu tahun, sejak 300 SM hingga 1600 M. Di Eropa sendiri, sejak tahun 300 SM hingga 1100 M, tidak ditemukan apa pun terkait aktivitas sains Kimia. Bangsa Arab yang kemudian berhasil mengembangkan sains Kimia sejak 650 M, dengan tokoh besarnya adalah Jabir ibn Hayyan (Geber) .

Ibn Khaldun dalam Muqaddimah mendefinisikan sains Kimia sebagai sains yang mempelajari substansi sesuatu, seperti bagaimana emas dan perak dapat dihasilkan. Kimia juga menerangkan cara-cara operasional untuk pengalihan substansi dari potensialitas ke aktualitas seperti disolusi tubuh kepada komponen naturalnya melalui sublimasi dan distilasi oleh solidifikasi substansi yang cair, juga melalui klasifikasi pulverisasi benda-benda keras dengan bantuan alat-alat penumbuk dan palu atau sejenisnya. Begitu besarnya kontribusi Jabir ibn Hayyan, sehingga terkadang ilmu ini disebut dengan ilmu Jabir. Jabir menulis tidak kurang dari tujuh puluh risalah kimia dan semuanya seakan seperti teka-teki. Hanya mereka yang menguasai pengetahuan yang terdapat dalam seluruh risalahnya yang dapat membuka kunci kimia.

John G. McEvoy, ketika menjelaskan tentang sejarah revolusi sains Kimia, menekankan bahwa pengajaran sejarah sains harus mengajarkan metode yang digunakan sehingga pengetahuan dapat diperoleh. Dalam hal ini sejarah sains diharapkan membawa kepada cara pandang baru terhadap kemanusiaan, sebagaimana pendapat George Sarton dan Charles Singer. John juga mengutip pendapat George Sarton bahwa eksistensi sains dibutuhkan sebagai kesatuan pengetahuan dan kesatuan alam.

Di bidang sains Kimia, peradaban Barat begitu tergantung dengan pencapaian peradaban Islam. Dalam hal ini, Pattison mengambil sosok Paracelsus, (lahir 1493 Einsiedeln, Switzerland) sebagai salah satu ahli Kimia paling terkenal di abad pertengahan. Awalnya, Paracelsus dikenal sebagai praktisi medis sekaligus dosen kedokteran yang telah melakukan perjalanan di sebagian besar wilayah Eropa, dan diyakini telah diajarkan penggunaan dari berbagai teori kedokteran baru dari ahli kedokteran Arab yang ditemuinya di Spanyol. Bagi Paracelsus, Kimia ada untuk mengekstrak saripati dari berbagai materi, dan untuk mempersiapkan senyawa rahasia dan ramuan yang dapat berfungsi untuk mengembalikan kesehatan manusia.

Material seperti plastik, rayon, karet buatan, bensin, bahan obat seperti insulin dan penisilin, dan semua hal-hal penting dalam industri kimia telah dimulai dari peradaban Muslim, yang diakui secara internasional telah melakukan revolusi sains Kimia, dengan tokoh-tokoh besarnya seperti Jabir Ibn Hayyan, Muhammad ibn Zakariya al-Razi dan alKindi. Khalid ibn Yazid ibn Mu'awiyah menjadi terkenal ketika dia menyerahkan tahta singgasananya di abad ke-8 M hanya untuk mempelajari Kimia dengan tujuan memberikan manfaat untuk saudara-saudaranya.

Ernst Von Meyer menjelaskan bahwa doktrin para ahli Kimia Arab, khususnya dari Jabir ibn Hayyan, secara bertahap mulai memasuki Perancis, Italia dan Jerman. Pengaruh dari dunia Timur ini dikenali secara jelas pertama kali pada seorang ahli Kimia di Jerman di 
istananya Adalbert von Bremen (sekitar tahun 1063), sebagaimana direkam oleh Adam von Bremen. Transformasi dari metal dasar ke dalam nobel oleh para ahli kimia (sebelumnya disebut dengan philosopher's stone) pada masa tersebut membentuk inti dari arah semua pengetahuan tentang kimia. Tokoh seperti Vinzenz of Beauvais (Vineentius Bellovacensis, awal abad ke-13 M), dan tokoh setelahnya seperti Albertus Magnus, Roger Bacon, Arnaldus Villanovanu, dan Raymund Lully, seluruhnya berada di abad yang sama, mengakui terjadinya transmutasi baja sebagai sebuah fakta tak terbantahkan. Dalam cara pandang terhadap komposisi logam yang terkait dengan kemampuan perubahan, maka mereka bisa disebut sebagai murid dari Jabir ibn Hayyan.

Khusus tentang sosok Jabir ibn Hayyan, menurut pendapat yang terkuat bahwa ia beragama Islam, paling tidak pada sebagian akhir hidupnya. Jabir ibn Hayyan menjelaskan teknik pendinginan yang dapat dipakai sebagai bagian proses penyulingannya. Beberapa hasil penyulingan berupa alkohol dimanfaatkannya untuk proses kimia dalam produksi asam, pengobatan, parfum, dan tinta untuk menulis, hal ini karena Islam melarang konsumi alkohol dan minuman yang mengandung racun. Bahkan di abad ini, Jabir telah mampu mengembangkan alembic still, yang masih digunakan hingga hari ini di setiap laboratorium penyulingan. Istilah 'alembic' ini berasal dari bahasa Arab, al-anbiq, ujung kepala dari still.

Di antara karya Jabir ibn Hayyan ditemukan teori-teori kimia baru tentang logam yang sangat spesifik yang telah berhasil dikembangkannya, disebarkan dengan otoritasnya sehingga meraih pengakuan internasional. Teori tersebut memandang kelas-kelas tubuh untuk pertama kalinya dari sudut pandang kimiawi, dan mencoba menjelaskan perbedaan antara substansi yang mengandung hal-hal ini, dengan mengasumsikan komposisi yang tidak umum. Logam, sebagaimana diajarkan oleh Jabir ibn Hayyan, terdiri dari sulfur dan merkuri dengan proporsi yang berbeda dan tingkat kemurnian tertentu. Terkadang, Jabir ibn Hayyan juga menambahkan unsur arsenik sebagai unsur ketiga yang paling memungkinkan.

Edgar F. Smith menegaskan bahwa harus menjadi kehormatan bagi bangsa Amerika untuk mengakui bangsa Arab sebagai bangsa pertama di mana sains Kimia menjadi sebuah pengetahuan yang sangat dibutuhkan secara luas. Bangsa Amerika berhutang kepada bangsa Arab seperti untuk penerapan sains Kimia dalam hal obat-obatan yang pertama kali dilakukan pada abad kesepuluh oleh Muhammad ibn Zakariya al-Razi (Rhases), seorang dokter dari rumah sakit Baghdad. Hal tersebut sekarang menjadi objek penting yang layak mendapatkan perhatian serius dari para pakar di Amerika. Demikian pula fenomena alam yang diteliti dengan penuh keseriusan oleh bangsa Arab, dimana proses baru disusun secara terstruktur untuk mendapatkan hukumnya, dan disusun agar terlihat sederhana, dianalisis agar ditemukan hal-hal baru. Begitulah situasi kimia di masa peradaban Islam memimpin, situasi yang sangat mendukung penyebaran ilmu pengetahuan, dan situasi seperti itu dicoba untuk ditransplantasikan ke Eropa Barat. Inilah sebagian dari alasan pentingnya mengajarkan sains dari perspektif sejarah pengembangannya, sebagaimana George Sarton telah menyusunnya secara detail dalam rentang setiap abad, khususnya pada 4 (empat) abad yang menentukan, abad ke $7 \mathrm{M}$ hingga $11 \mathrm{M}$.

Pada paruh kedua abad ke-7 menjadi awal penerjemahan literatur Yunani ke dalam bahasa Arab, hal ini berawal dari ketertarikan Pangeran Bani Umayyah, Khālid bin Yazīd (wafat tahun 704M atau 708M), dipanggil dengan Hakim, dari keluarga Marwan, yang tinggal di Mesir, terhadap sains dan filsafat Yunani, khususnya kedokteran, astrologi, dan kimia. Beragam karya-karya di bidang Kimia termasuk yang telah ditranslasikan oleh beliau. George Sarton mengutip pernyataan Fihrist: "Inilah penerjemahan pertama di dalam Islam dari satu bahasa ke bahasa yang lain.” Khālid bin Yazīd sendiri diyakini telah belajar kimia dari seorang sarjana Alexandria yang bernama Marianos (Morienus Romanus, Morienes). Karya Marianos adalah sebuah risalah kimia yang diperoleh Sarton dari teks berbahasa Latin yang ditulis oleh Robert of Chester. Selebihnya tidak ditemukan aktifitas saintifik yang lebih detail yang telah 
dilakukan oleh Khālid bin Yazīd. Meskipun banyak tulisan di bidang Kimia yang bersumber darinya, namun tidak mungkin untuk memvalidasinya. Bahkan buku "Book of Crates", satusatunya karya berbahasa Arab yang diyakini ditulis di masa Khalid, tidak dapat dipastikan bersumber darinya.

Pada paruh pertama abad ke-8, George Sarton mencatat nama Abu 'Abdallah Ja'far alSādiq ibn Muhammad al-Bāqir ibn 'Ali Zain al-'Ābidin ibn al-Husain ibn 'Ali ibn Abi Thālib (699 M - $765 \mathrm{M})$ yang diketahui menulis beberapa risalah Kimia. Sarton mengutip Fihrist, bahwa dia adalah guru dari Jābir ibn Haiyān. Beragam risalah astrologi, kimia dan hal-hal ghaib telah ditulisnya. Dalam hal ini, Sarton merujuk kepada satu teks karya Imam Ja'far, Kitāb risālah Ja'far al-Sādiq fị 'ilm al-sanā'a wa al-hajar al-mukarram, yang dipublikasikan oleh Ruska dengan terjemahan berbahasa Jerman yang diberikan judul Book of the Epistle of Ja'far on the Science of the Art and the Noble Stone (Heidelberg, 1924), dengan masa terbit sekitar abad ke-11 hingga abad ke-13.

Pada paruh kedua abad ke-8, George Sarton mencatat bahwa karya pertama di bidang Kimia dalam bahasa Arab dan Latin muncul pada saat yang bersamaan. Hal ini tentunya jika penghitunggan tanggal keduanya benar. Ahli Kimia terkenal Islam adalah Abū Mūsa Jābir ibn Haiyān al-Azdi (al-Tūsī, al-Tartūsī, al-Harrānī, terkenal di Kūfa, 776 M) yang terlihat memiliki pengetahuan eksperimen yang baik terhadap sejumlah fakta kimia. Dia pun seorang yang pintar dalam membuat teori.

Jābir ibn Hayyān menulis sebuah buku tentang astrolabe, dan banyak buku lainnya yang telah diterjemahkan ke dalam bahasa Inggris berjudul: Book of Kingdom, Little Book of the Balances, Book of Mercy, Book of Concentration, Book of Eastern Mercury, dan lainnya. Metode yang dilakukannya dalam melakukan riset kimia sangat baik. Demikian pula teori yang dibuat seperti formasi geologi logam, teori sulfur-merkuri tentang logam (terdapat enam jenis logam yang berbeda secara mendasar dikarenakan perbedaan proporsi sulfur dan merkuri di dalamnya), pengolahan beragam zat kimia (seperti karbonat dasar, arsenik, dan antimoni dari sulfida. Jābir ibn Haiyān juga melakukan beberapa aktifitas seperti pemurnian logam, pengolahan baja, pencelupan baju dan kulit, mempernis hingga membuat tahan air pakaian dan melindung besi penggunaan manggan dioksida dalam pembuatan kaca, penggunaan cairan besi untuk membuat tulisan di atas emas, penyulingan cuka untuk memusatkan asam asetat. Dia juga menguji kekuatan magnet.

Bagi George Sarton, sangat memungkinkan bahwa beberapa fakta yang dimunculkan dalam karya-karya Latin adalah penemuan dari Jābir ibn Haiyān, khususnya yang mulai diterbitkan sejak abad ke-12. Meskipun pada masanya, George Sarton belum mempelajari secara keseluruhan semua karya-karya berbahasa Arab terkait Kimia, namun dari apa yang didapatnya sementara sudah menunjukkan bahwa Jābir ibn Haiyān memiliki kepribadian yang luar biasa, dan menjadi sosok terbaik bagi sains abad pertengahan. Beberapa karyanya dalam bahasa Arab diedit oleh Octave Houdas, maupun terjemahan dalam bahasa Perancis oleh Erns Darmstaedter berjudul Die Alchemie des Geber.

Buckley menyebutkan bahwa Jābir ibn Haiyān merupakan Bapak Kimia (Founder of Chemistry). Gelar ini sebagai apresiasi atas porsi besar waktunya dalam penelitian di bidang Kimia, bahkan menjadi orang yang pertama di masa abad pertengahan. Menurut Buckley, Jābir ibn Haiyān telah menjelaskan dalam karya-karyanya banyak metode penelitian yang kemudian banyak digunakan oleh para saintis kimia di masa sekarang.

Pada paruh pertama abad ke-9, aktivitas para sarjana dan pakar sains Muslim sangatlah unggul. Apa yang telah mereka lakukan telah melahirkan standar peradaban sesungguhnya di masa tersebut. Al-Kindī membuat risalah di bidang geometri dan optik fisiologis, dan dia mengkritik kimia. 
Aktivitas yang telah dimulai oleh umat Islam di bidang sains sejak awal paruh pertama abad ke-9 terus memenuhi ruang abad ini, sehingga keseluruhan abad ini bisa disebutkan adalah abadnya umat Islam. Pada paruh kedua abad ini, aktivitas umat Islam semakin membesar, di mana secara praktis semua pemimpin ilmuwan Islam adalah Muslim, yang banyak bekerja untuk Muslim dan menulis dalam bahasa Arab. Pada masa ini tercatat 4 (empat) nama ahli Kimia Muslim: Dhū-l-nūn, al-Jāhiz, al-Rāzi, dan al-Nairīzī.

Bagi Muslim, Dhū-l-nūn (Abū-l-Fayd Thawbān ibn Ibrāhīm al-Ikhmīmī, al-Misrī, berasal dari Nubia atau Ikhmìm di Mesir bagian atas, wafat 859-860) adalah ahli kimia. Namun bagi George Sarton, karena Dhū-l-nūn juga seorang sufi, dia lebih mirip ahli Kimia Tao, karena lebih ke arah metafisis dan gambaran sains yang jarang sekali melibatkan pengujian atau eksperimen. Di dalam Fihrist, dia diklasifikasikan ke dalam kelompok ahli Kimia dan Ibn alQiftī menggolongkannya bersama Jābir ibn Hayyān.

Al-Jāhiz (Abū 'Uthmān 'Amr ibn Bahr al-Jāhiz, terkenal di Basra, wafat 868-869 M, pada usia 90-an tahun) terlihat memiliki pengetahuan di bidang Kimia, misalkan bahwa dia mengetahui bagaimana cara mendapatkan amoniak dan salmiac dari kotoran hewan dengan penyulingan kering, namun George Sarton masih merasa terlalu terburu-buru untuk menyebutnya seorang kimiawan.

Di sisi lain, seorang ahli kedokteran terbaik di dalam dunia Islam, Rhazes atau al-Rāzi (Abū Bakr Muhammad ibn Zakarīyā al-Rāzi, lahir di Ray, dekat Teheran, Persia di pertengahan abad ke-9, terkenal di Ray dan Baghdad, dan wafat 923 M) tidak diragukan lagi boleh disebut sebagai ahli Kimia sesungguhnya karena aktifitasnya di dalam menulis beragam risalah seputar kimia, menjelaskan sejumlah instrumen kimia, melakukan klasifikasi substansi mineral, dan bahkan mencoba menerapkan pengetahuan kimianya untuk tujuan pengobatan. Beberapa karya di bidang Kimia telah ditulisnya, seperti Arcandorum Liber, apcryphal, yang berisi 25 bagian tentang kimia. Dia juga telah membuat klasifikasi tentang substansi Kimia.

Dengan upayanya itu, al-Rāzi disebut sebagai nenek moyangnya iatrochemist di abad ke16. Dia adalah pendahulu iatrochemists di masa Renaissans dengan karyanya besarnya, sebuah ensiklopedi kedokteran yang disebut al-Hāwī (Continens), dan sebuah monograf (Kitäb al-jadari wal-hasba; De variolis et morbiliis; De Peste; De pestilentia) tentang penyakit campak dan cacar yang sangat dikenal dalam dunia pengobatan Muslim. Dia mengombinasikan teori Galen dengan pengetahuannya yang luas tentang kebijaksanaan Hipokratik. Kitab lain yang ditulisnya, Kitäb al-Mansūrn̄ (Liber Almansoris, sebuah kompilasi kecil dari sepuluh buku yang sebagian besarnya dari sains Yunani. Demikian pula banyak hal seputar ginekologi, kebidanan, dan operasi mata yang merujuk kepada tulisannya.

Al-Rāzi berhasil menemukan banyak penemuan di bidang Kimia seperti pemaparan dua puluh peralatan kimia yang digunakan di masanya, baik yang terbuat dari kaca maupun logam. Dia membagi bahan-bahan kimia kepada empat kategori, yaitu logam, nabati, hewan dan campuran. Dia berhasil memadukan sebagian zat asam di antaranya adalah sulfur yang kemudian dinamakan zait al-zaj atau albir al-kabir. Dia mampu mengeluarkan alkohol dari tetesan tajin dan gula yang telah menjadi khamr, kemudian digunakannya untuk pengobatan dan berbagai keperluan medis lain. Dia juga mampu mengukur kadar jenis minuman keras dengan menggunakan skala khusus yang disebut dengan skala alami.

Anaritius atau al-Nairīzì (Abū-l-'Abbas al-Fadl ibn Hātim al-Nairīzī, dari Nairīz, dekat Shīrāz), menulis sebuah kitab tentang fenomena atmosfer untuk Khalifah al-Mu'tadid (memimpin dari $892-902 \mathrm{M}$, wafat $922 \mathrm{M}$ ).

Memasuki abad ke-10 M, Ibn Wahshīya (Abū Bakr Ahmad ibn 'Alī ibn al-Wahshīya alKaldānī al-Nabatī, lahir di Irak, dari keluarga Nabataean) dikenal di masa ini sebagai seorang 
ahli kimia dan okultis, sebagaimana juga tercatat dalam Fihrist . Karyanya memang tidak terlihat ada yang penting, namun dapat membantu memahami simbol-simbol kimia.

Karya saintifik pertama di era Persia Modern (era dimana kaum Muslim Persia telah menulis dalam bahasa Arab hingga saat ini) telah menjadi salah satu karya terpenting di bidang Kimia yang ditulis oleh Muslim pada paruh kedua abad ke-10 M. Karya tersebut merupakan sebuah risalah tentang materia medica namun mengandung informasi berlimpah tentang pengolahan dan properti dari kandungan mineral, ditulis oleh Abū Mansūr Muwaffak.

Abū Mansūr Muwaffak ibn 'Ali al-Harawi, menjadi yang pertama memiliki ide menyusun risalah medis terbaik di Persia. Risalah tersebut berisi materia medica dan mengandung secara garis besar teori farmakologi. Karyanya ditulis dengan mengumpulkan informasi melalui perjalanan bolak balik antara Persia dan India. Secara intrinsik nilainya sangat baik, dan secara ekstrinsik juga sangat penting karena menjadi karya prosa tertua di Persia modern, yakni Book of Foundations of the True Properties of the Remedies (Kitäb al-abniya 'an haqä iq aladwiya), gabungan beragam elemen yang diperoleh dari Yunani, Syiria, Arab, dan Hindu, ditulis pada rentang tahun 968-977 M. Kitab ini juga berisi 585 obat dimana 466 obat dari tanaman, 75 obat dari mineral, dan 44 obat dari hewan. Beliau mampu membedakan antara sodium carbonate (natrūn) dan potassium carbonate (qlī); menjelaskan tentang arsenious oxie, cupric oxide, silicic acid, dan antimon; memahami efek toksikologi dari tembaga dan senyawa timbal, manfaat kapur mentah untuk menghilangkan rambut, komposisi plester Paris dan penggunaan untuk proses bedah.

Karya tulis di bidang medis yang ditulis oleh ahli bedah Muslim terbaik, Abū-l-Qāsim Khalaf ibn 'Abbās al-Zahrāwī (Abulcasis, Albucasis, Alsaharavius; wafat 1013 M) berisi beragam hal tentang kimia, juga penjelasan tentang pengolahan obat-obatan dengan sublimasi dan distilasi. Karya ensiklopedi medis ini terdiri atas 30 bab berjudul al-tasriff (Vade mecum), berisi metode menarik dalam menyiapkan obat melalui proses sublimasi dan distilasi. Karya lainnya yang cukup penting adalah tentang bedah dalam 3 (tiga) buku, yang sebagian besar berdasarkan pada karya Paulos Aegineta. Di dalamnya terlampir permasalahan proses pembakaran untuk membunuh kuman dan (cauterization) dan obat untuk penahan darah (styptics). Permasalahan bedah yang dibahas adalah seputar masalah kebidanan dan pembedahan mata, telinga, dan gigi. Karya ini dilengkapi dengan gambaran tentang perlengkapan bedah. Awalnya ia diterjemahkan ke dalam Latin oleh Gherardo Cremonese, dan ke dalam Provençal dan Ibrani.

Dua karya kimia penting lain juga telah dibuat oleh Abū-l-Qāsim Maslama ibn Ahmad al-Majrìtī (lahir di Madrid, wafat sebelum 1007 M), yakni Sage's Step (Rutbat al-Hakìm) dan Aim of the Wise (Ghāyat al-Hakīm). Kandungan dari kedua kitab itu merupakan hasil dari filsafat dan buah ilmu-ilmu pengetahuan, dan barang siapa tidak menguasainya akan kehilangan buah ilmu dan filsafat keseluruhannya. Tulisan yang terakhir ini sangat dikenal dalam terjemahan Latin yang dibuat pada tahun $1252 \mathrm{H}$ atas perintah Raja Alfonso berjudul Picatrix. Kemungkinan teks asli berbahasa Arabnya ada di pertengahan abad ke-11. Kitab Rutbat al-Hakim dianggap sebagai satu dari sumber rujukan yang paling penting tentang sejarah perkembangan sains Kimia di negeri Spanyol. Di antara isinya adalah tentang pembuatan merkuri oksida dari merkuri, sebuah eksperimen kuantitatif.

Abu Bakr ibn Bisyrun, murid dari al-Majrītī menyebutkan bahwa sebelum mempelajari sains Kimia, murid harus mengetahui tiga hal, yakni apakah ia ada, dari apa ia ada, dan bagaimana ia ada. Apabila para pelajar sains Kimia mengetahui ketiga hal itu dengan baik, ia akan mencapai tujuannya dan mengetahui seberapa jauh yang akan diketahuinya tentang sains ini. Bagi Ibn Khaldun, sains Kimia menjadi salah satu jalan dimana jiwa spiritual 
mempengaruhi dan aktif di alam tabiat. Ia masuk ke bagian karamah apabila jiwanya baik, atau ia termasuk sihir kalau jiwanya buruk dan jahat.

Memasuki abad ke-11 M, hadir Ibn Sīnā yang berhasil menjaga pandangan asli tentang kimia. Dia berbeda dengan keyakinan umum dari ahli kimia Muslim bahwa mewarnai atau menjadikan logam berwarna merah tua akan mempengaruhi substansi mereka, dia berpikir bahwa perbedaan antara logam terlalu dalam untuk menyebabkan terjadinya transmutasi.

Rekan Ibn al-Haitham di Akademi Kairo, Māsawaih al-Mārdīnī, menjelaskan tentang pengolahan minyak empyreumatic. Adapun risalah penting tentang Kimia disusun di tahun 1034 M olah Abū-l-Hakim Muhammad ibn 'Abd al-Malik al-Sālihī al-Khwārizmī al-Kāthī. Risalah itu berjudul 'Ain al-San'a wa 'Awn-al-Sana'à (Essence of the Art and Aid to the Workers), mirip dengan Summa perfectionis magisterii dari karya Latin Geber (Jābir) di paruh kedua abad ke-8 M.

\section{Analisis Tujuan dan Nilai Pengajaran Kimia}

Dalam silabus mata pelajaran Kimia Sekolah Menengah Atas/Madrasah Aliah (SMA/MA) yang disusun Kementrian Pendidikan dan Kebudayaan di Jakarta, 2016, dipaparkan bahwa setelah peserta didik mengikuti pembelajaran Kimia di SMA/MA diharapkan memiliki kompetensi yang mencakup kompetensi sikap, kompetensi pengetahuan, dan kompetensi keterampilan sebagai berikut ini.

1. menjalani kehidupan dengan sikap positif dengan daya pikir kritis, kreatif, inovatif, dan kolaboratif, disertai kejujuran dan keterbukaan, berdasarkan potensi proses dan produk kimia;

2. memahami fenomena alam di sekitarnya, berdasarkan hasil pembelajaran sains melalui bidang-bidang Kimia;

3. membedakan produk atau cara yang masuk akal dengan produk atau cara yang tidak bersesuaian dengan prinsip-prinsip Kimia;

4. mengambil keputusan di antara berbagai pilihan yang dibedakan oleh hal-hal yang bersifat ilmiah;

5. menyelesaikan masalah yang dihadapi dalam kehidupannya, terutama memilih di antara cara-cara yang telah dikenal manusia berdasarkan pertimbangan ilmiah; dan

6. mengenali dan menghargai peran Kimia dalam memecahkan permasalahan umat manusia; dan

7. memahami dampak dari perkembangan Kimia terhadap perkembangan teknologi dan kehidupan manusia di masa lalu, maupun potensi dampaknya di masa depan bagi dirinya, orang lain, dan lingkungannya.

\section{E. Analisis Standar Kompetensi (SK) dan Kompetensi Dasar (KD)}

Kerangka pengembangan Kompetensi Dasar (KD) Ilmu Pengetahuan Alam mengacu pada Kompetensi Inti (KI) sebagai unsur pengorganisasi KD secara vertikal dan horizontal. Organisasi vertikal KD berupa keterkaitan KD antar kelas harus memenuhi prinsip belajar, yaitu terjadi suatu akumulasi yang berkesinambungan antar kompetensi yang dipelajari peserta didik. Organisasi horizontal berupa keterkaitan antara KD suatu mata pelajaran dengan KD mata pelajaran lain dalam satu kelas yang sama sehingga terjadi proses saling memperkuat. Pengembangan kompetensi dasar berdasarkan pada prinsip akumulatif, saling memperkuat (reinforced) dan memperkaya (enriched) antar-mata pelajaran dan jenjang pendidikan (organisasi horizontal dan vertikal). Semua kompetensi dasar dan proses pembelajaran dikembangkan untuk mencapai KI. 
Kompetensi Inti terdiri dari 4 (empat) aspek, yaitu: KI-1 (sikap spiritual), KI-2 (sikap sosial), KI-3 pengetahuan, dan KI-4 (keterampilan). KD Sikap Spiritual dan KD Sikap Sosial pada mata pelajaran Kimia tidak dirumuskan, tetapi hasil pembelajaran kompetensi sikap dicapai secara tidak langsung (indirect teaching) dari pengetahuan dan keterampilan, sehingga perlu direncanakan pengembangan sikap dalam pembelajaran. KI-3 pengetahuan dan KI-4 keterampilan dirinci lebih lanjut dalam KD mata pelajaran. Pengembangan KD tidak dibatasi oleh rumusan Kompetensi Inti (KI), tetapi disesuaikan dengan karakteristik mata pelajaran, kompetensi, lingkup materi, psikopedagogi. Namun demikian, perumusan KD harus mengacu ke Kompetensi Inti.

Table I: Kompetensi Inti Mata Pelajaran Kimia SMA

\begin{tabular}{l}
\hline Kelas XII \\
\hline KI-I: Menghayati dan mengamalkan ajaran agama yang dianutnya. \\
\hline KI-2: Menunjukkan perilaku jujur, disiplin, tanggungjawab, peduli (gotong royong, kerjasama, \\
toleran, damai), santun, responsif dan pro-aktif dan menunjukkan sikap sebagai bagian dari solusi \\
atas berbagai permasalahan dalam berinteraksi secara efektif dengan lingkungan sosial dan alam \\
serta dalam menempatkan diri sebagai cerminan bangsa dalam pergaulan dunia. \\
\hline KI-3: Memahami, menerapkan, menganalisis dan mengevaluasi pengetahuan faktual, konseptual, \\
prosedural, dan metakognitif berdasarkan rasa ingin tahunya tentang ilmu pengetahuan, \\
teknologi, seni, budaya, dan humaniora dengan wawasan kemanusiaan, kebangsaan, kenegaraan, \\
dan peradaban terkait penyebab fenomena dan kejadian, serta menerapkan pengetahuan \\
prosedural pada bidang kajian yang spesifik sesuai dengan bakat dan minatnya untuk \\
memecahkan masalah. \\
\hline KI 4: Mengolah, menalar, menyaji, dan mencipta dalam ranah konkret dan ranah abstrak terkait \\
dengan pengembangan dari yang dipelajarinya di sekolah secara mandiri serta bertindak secara \\
efektif dan kreatif, dan mampu menggunakan metode sesuai kaidah keilmuan. \\
\hline
\end{tabular}

\section{F. Analisis Isi Buku Kimia XII A}

Secara umum, isi buku Kimia XII A lebih menitikberatkan kepada kompetensi pengetahuan dan keterampilan. Padahal dalam silabus dijelaskan bahwa pelajaran Kimia harus membangun kompetensi Inti yang terdiri dari 4 (empat) aspek, yaitu: KI-1 (sikap spiritual), KI-2 (sikap sosial), KI-3 pengetahuan, dan KI-4 (keterampilan). Walaupun dijelaskan bahwa KD Sikap Spiritual dan KD Sikap Sosial pada mata pelajaran Kimia tidak dirumuskan, tetapi hasil pembelajaran kompetensi sikap dicapai secara tidak langsung (indirect teaching) dari pengetahuan dan keterampilan, sehingga perlu direncanakan pengembangan sikap dalam pembelajaran. Akan tetapi, sebenarnya kita bisa memasukan nilai-nilai spiritual secara langsung ke dalam buku teks kimia sehingga akan membangun sikap spiritual seorang siswa. Langkah-langkah memasukkan nilai-nilai spiritual ini diistilahkan dengan islamisasi, yang Insya Allah akan dijelaskan pada bab berikutnya.

\section{G. Panduan Islamisasi Buku Ajar Kimia XII A}

Istilah Islamisasi memang istilah baru yang belum ada di masa jaman keemasan Islam. Akan tetapi, pelabelan Islami menjadi penting saat ini sebagai mana dijelaskan oleh Osman Bakar bahwa istilah Islami itu diperlukan manakala untuk membedakan antara segala sesuatu yang dipandang "Islami" dan yang dipandang "tidak Islami”. Ini khususnya berlaku ketika segala sesuatu itu demikian sangat penting sehingga ketidakmampuan dalam melakukan pembedaan yang diperlukan bisa menimbulkan kebingungan dan kerancuan dalam pemikiran kaum muslimin dan berdampak negatif pada pemahaman mereka dan pengamalan agama Islam berikut peradabannya (Bakar, 2008).

Kebutuhan akan istilah definitif "Islami" juga sangat jelas dan gamblang bagi siapa saja yang cukup akrab serta mengenal sains Islam dan sains Barat modern. Kedua sains ini memiliki perbedaan jelas dalam sifat dan karakter filosofisnya. Walaupun kedua sains tersebut 
memiliki perbedaan yang jelas, masih banyak kaum muslimin yang bingung tentang sifat dan karakter sebenarnya dan juga tentang kaitan historis sesungguhnya dari dua sains tersebut. Dengan sendirinya, ada kebutuhan nyata untuk memahami dengan benar masing-masing sifat dan, karakter dan historisnya (Husaini \& al, 2013).

Islamisasi menurut $\mathrm{Al}-\mathrm{Attas}$ adalah pembebasan manusia dari unsur magic, mitologi, animisme, dan tradisi kebudayaan kebangsaan serta penguasaan sekuler atas akal dan bahasanya. Ini berarti pembebasan akal atau pemikiran dari pengaruh pandangan hidup yang diwarnai oleh kecenderungan sekuler, primordial, dan mitologis.

Islamisasi ilmu pengetahuan yang digagas oleh Al-Attas ini dilatarbelakangi oleh tiga temuan ilmiahnya, yaitu: (1) problem terpenting yang dihadapi umat Islam saat ini adalah masalah ilmu pengetahuan; (2) ilmu pengetahuan modern tidak bebas nilai (netral), sebab dipengaruhi oleh pandangan-pandangan keagamaan, kebudayaan dan filsafat yang mencerminkan kesadaran dan pengalaman manusia Barat; dan (3) umat Islam, oleh karena itu, perlu mengislamkan ilmu pengetahuan masa kini dengan mengislamkan simbol-simbol linguistik mengenai realitas dan kebenaran(Husaini \& al, 2013).

Al-Faruqi mendefinisikan Islamisasi ilmu sebagai usaha dalam memberikan definisi baru, mengatur data-data, memikirkan lagi jalan pemikiran dan menghubungkan data-data, mengevaluasi kembali kesimpulan-kesimpulan, memproyeksikan kembali tujuan-tujuan dan melakukan semua itu sedemikian rupa sehingga disiplin-disiplin itu memperkaya wawasan Islam dan bermanfaat bagi cause (cita-cita) Islam (al-Faruqi, 1984).

Sebelum melangkah lebih jauh, paradigma berpikir mengenai Islamisasi harus disamakan. Bahwa Islamisasi yang dimaksud di sini adalah mengislamkan ilmu pengetahuan Barat modern kontemporer, tidak termasuk turast Islami. Ilmu ini (turast) tidak pernah terpisah dari Tuhan sebagai hakikat sebenarnya dan sumber ilmu pengetahuan. Jadi ketika digunakan ungkapan Islamisasi ilmu pengetahuan, yang dimaksud adalah ilmu pengetahuan kontemporer, yang diproyeksikan melalui pandangan hidup budaya dan peradaban barat. Menurut al-Attas ada lima faktor yang menjiwai budaya dan peradaban Barat: 1) Akal diandalkan untuk membimbing kehidupan manusia; 2) Bersikap dualistik terhadap realitas dan kebenaran; 3) Menegaskan aspek eksistensi yang memproyeksikan pandangan hidup sekuler; 4) Membela doktrin humanisme; dan 5) Menjadikan drama dan tragedi sebagai unsur-unsur dominan dalam fitrah dan eksistensi kemanusiaan (Alim, 2012).

\section{Konsep Islamisasi}

Ada dua metode yang dijelaskan oleh al-Attas dalam melakukan proses islamisasi. Pertama ialah melakukan proses pemisahan elemen-elemen dan konsep-konsep kunci yang membentuk kebudayaan dan peradaban Barat. Kedua, memasukkan elemen-elemen Islam dan konsep-konsep kunci ke dalam setiap cabang ilmu pengetahuan masa kini yang relevan (Handrianto, 2010).

Sedangkan konsep Islamisasi sains menurut al-Faruqi dapat dipahami melalui proses integrasi, yaitu mengintegrasikan sains Barat dengan ilmu-ilmu Islam. Menurutnya, akar dari kemunduran umat Islam di berbagai dimensi karena dualisme sistem pendidikan. Di satu sisi, sistem pendidikan Islam mengalami penyempitan makna dalam berbagai dimensi, sedangkan di sisi yang lain, pendidikan sekuler sangat mewarnai pemikiran kaum Muslimin. Menurutnya, mengatasi dualisme sistem pendidikan ini merupakan tugas terbesar kaum Muslimin pada abad ke-15 H. Al-Faruqi menyimpulkan solusi dualisme dalam pendidikan dengan islamisasi ilmu sains. Sistem pendidikan harus dibenahi dan dualisme sistem pendidikan harus dihapuskan dan disatukan dengan jiwa Islam dan berfungsi sebagai bagian yang integral dari paradigmanya. Al-Faruqi menjelaskan pengertian Islamisasi sains sebagai usaha yaitu memberikan definisi baru, mengatur data-data, memikirkan lagi jalan pemikiran dan 
menghubungkan data-data, mengevaluasi kembali kesimpulan-kesimpulan, memproyeksikan kembali tujuan-tujuan dan melakukan semua itu sehingga disiplin-disiplin itu memperkaya wawasan Islam dan bermanfaat bagi cita-cita Islam (Handrianto, 2010).

Konsep Islamisasi sains berikutnya menggunakan pendekatan sakralisasi. Ide ini dikembangkan pertama kali oleh Seyyed Hossein Nasr. Menurutnya, sains modern yang sekarang ini bersifat sekuler dan jauh dari nilai-nilai spiritualitas sehingga perlu dilakukan sakralisasi. Nasr mengkritik sains modern yang menghapus jejak Tuhan di dalam keteraturan alam. Alam bukan lagi dianggap sebagai ayat-ayat Allah tetapi entitas yang berdiri sendiri. Ia bagaikan mesin jam yang bekerja sendiri. Ide sakralisasi sains mempunyai persamaan dengan proses islamisasi sains yang lain dalam hal mengkritik sains sekuler modern. Namun perbedaannya cukup mencolok karena menurut Nasr, sains sakral (sacred science) dibangun di atas konsep semua agama sama pada level esoteris (batin) (Handrianto, 2010).

Menurut Budi Handrianto Islamisasi sains seharusnya dibangun di atas kebenaran Islam. Sains sakral menafikan keunikan Islam karena menurutnya keunikan adalah milik semua agama. Sedangkan islamisasi sains menegaskan keunikan ajaran Islam sebagai agama yang benar. Oleh karena itu, sakralisasi ini akan tepat sebagai konsep Islami sasi jika nilai dan unsur kesakralan yang dimaksud di sana adalah nilai-nilai Islam (Handrianto, 2010).

\section{Konsep Islamisasi pada Buku Ajar}

Konsep Islamisasi pada buku ajar sebenarnya sama dengan konsep islamisasi sains secara umum. Akan tetapi, Islamisasi dalam buku ajar lebih spesifikasi kepada muatan materi yang ada dalam buku. Adapun langkah-langkah yang digunakan dalam penelitian ini, mengacu pada penelitian yang dilakukan oleh Wendi Zarman pada disertasinya yang berjudul Studi Pengembangan Buku Teks Ilmu Pengetabuan Alam Sekolah Menengah Pertama Berbasis Nilai Keimanan, dengan langkah-langkah sebagai berikut:

a. Memberikan pengantar yang berisikan nasihat-nasihat Islami

b. Menyisipkan ungkapan kemahakuasaan Allah

c. Mengungkapkan hikmah penciptaan alam yang menumbuhkan syukur

d. Mengoreksi konsep yang bertentangan dengan ajaran Islam

e. Memasukkan ayat Al-Qur'an atau hadits yang relevan

f. Memasukkan informasi kiprah ilmuwan muslim dan

g. Mengaitkan materi dengan penerapan ajaran Islam.

\section{Internalisasi Nilai Keislaman Pada Buku Ajar Kimia SMA Kelas XII}

1. Memberikan Pengantar Yang Berisikan Nasihat-Nasihat Islami

Kata pengantar atau pendahuluan merupakan bagian terpenting dalam sebuah buku. Sebuah pendahuluan menjelaskan berbagai aspek yang terkait dengan penulisan buku tersebut seperti latar belakang mengapa buku tersebut ditulis, tujuan penulisannya, gambaran umum isinya, manfaat-manfaat yang bisa diperoleh darinya, saran-saran mengenai cara menggunakannya, harapan-harapan dari penulisnya, dan lain sebagainya. Adapun langkahlangkahnya sebagai berikut: Pertama, memulai dengan basmalah, "Dengan menyebut nama Allah Yang Maha Pengasih lagi Maha Penyayang" karena memulai suatu pekerjaan baik dengan membaca basmalah merupakan sunnah Nabi yang sangat utama. Kedua, memuji Allah (bamdalab) sambil merendahkan diri dengan mengatakan bahwa selesainya penulisan buku itu tidak lain adalah karena pertolongan-Nya. Ketiga, menyampaikan shalawat kepada Nabi Muhammad shallallâbu 'alaibi wasallam yang menjadi panutan utama seluruh umat Islam. Keempat, mengemukakan niat dengan memohon agar penulisan buku tersebut dicatat menjadi 
amal shalih yang bernilai pahala di sisi Allah. Kelima, memintakan ampun atas kekhilafan yang mungkin mereka lakukan dalam penulisan buku tersebut. (Zarman, 2012)

Adapun buku ajar Kimia kelas XII yang ditulis oleh Ari Hartono, Ruminten, Iman Rahayu, dan Suwardi dkk, luput dari hal-hal yang telah disebutkan di atas. Secara umum pengantar buku-buku tersebut hanya mengulas upaya proses pencetakan dan harapkan bahwa buku teks pelajaran ini akan lebih mudah diakses sehingga siswa dan guru di seluruh Indonesia maupun sekolah Indonesia yang berada di luar negeri dapat memanfaatkan sumber belajar ini.

Isi pengantar masih terasa umum dan tidak sarat dengan nilai keimanan sebagai landasan dan tujuan pendidikan. Padahal menurut Zarman pengantar ini dapat digunakan untuk memberi motivasi religius kepada siswa, misalnya tentang apa tujuan mempelajari alam.

2. Menyisipkan Ungkapan Kemahakuasaan Allah

Zarman menjelaskan bahwa para ilmuwan Muslim di masa silam sering kali mengaitkan penulisan suatu karya intelektual dengan Tuhan dan agama, tidak terkecuali ketika mereka menulis buku sains. Pengaitan ini bukan saja dalam pembahasan mengenai alam secara umum tetapi juga ketika berbicara soal masalah teknis sains yang terperinci. Mereka sering kali mengungkapkan keagungan atau kemahakuasaan Allah di dalam buku karya mereka. Mereka memasukkan unsur penanaman nilai keimanan di dalam buku teks tersebut, dengan cara dimasukkan kata-kata Allah ke dalam kalimat yang relevan dan menyandingkannya dengan ungkapan-ungkapan yang menunjukkan sifat-sifat rububiyyah Allah seperti mencipta, memelihara, mengatur, memberi rizki, atau kata-kata lain yang mengindikasikan makna serupa(Zarman, 2012).

Ia mencontohkan sebuah buku yang ditulis Zakariya al-Razi, ahli kimia, dalam karyanya Buku Rabasia-Rabasia yang merupakan sebuah buku ilmu kimia. Di dalam buku ini al Razi menjelaskan tentang pembuatan larutan kalsium polisulfida yang di bagian akhirnya ia menulis: "Dan Allah Maha Tahu apa yang terbaik". Ungkapan seperti ini menurut Zarman, sekurangnya merefleksikan dua hal. Pertama, sikap tawakal al-Razi terhadap ketetapan Allah terhadap percobaannya yang juga sekaligus bentuk pengakuan ketidakmampuannya dalam menciptakan bahan kimia apapun, bahwa apapun hasil pencampuran zat-zat kimia tersebut, semuanya berada di dalam kendali Allah. Kedua, ungkapan al-Razi 'Allah tahu apa yang terbaik' mengindikasikan pengakuan al-Razi terhadap kebaikan dan kesempurnaan ketetapan Allah tersebut.

Dalam buku Panduan Pembelajaran Kimia XII Untuk SMA \& MA, bab 1 mengenai sifatsifat koligatif larutan di halaman 2, kita bisa menyisipkan ungkapan kemahakuasaan Allah. Dalam tulisan yang ada buku adalah sebagai berikut:

Pada umumnya bahan yang kita jumpai dalam kehidupan sehari-hari adalah campuran dari zat-zat murni. Banyak dari campuran ini adalah homogen, yaitu komponennya terdispersi secara homogen pada tingkat molekular. Campuran homogen disebut juga larutan. Contoh larutan melimpah di sekitar kita. Udara yang kita hirup adalah larutan dari beberapa gas. Kuningan adalah larutan padat dari seng dalam tembaga. Zat cair yang mengalir dalam tubuh kita adalah larutan, yang membawa berbagai nutrien esensial, garam-garam, dan bahan lain. Air sungai juga terdiri dari campuran berbagai zat.

Kalimat-kalimat di atas memiliki makna netral dari unsur penanaman nilai keimanan kepada Allah. Ditinjau dari redaksi kalimatnya, bahan-bahan yang dapat dijumpai dalam kehidupan manusia ada begitu saja dan terjadi tanpa adanya campur tangan Allah dalam proses terbentuknya. Kalimat di atas bisa kita sisipkan nilai-nilai keimanan sebagai berikut.

Allah telah menciptakan bumi ini terdiri dari bahan-bahan yang berguna untuk umat manusia. Pada umumnya, bahan-bahan yang telah Allah ciptakan, yang kita 
jumpai dalam kehidupan sehari-hari adalah campuran dari zat-zat murni. Banyak dari campuran ini adalah homogen, yaitu komponennya terdispersi secara homogen pada tingkat molekular. Campuran homogen disebut juga larutan. Contoh larutan melimpah di sekitar kita. Udara yang kita hirup adalah larutan dari beberapa gas. Kuningan adalah larutan padat dari seng dalam tembaga. Zat cair yang mengalir dalam tubuh kita adalah larutan, yang membawa berbagai nutrien esensial, garam-garam, dan bahan lain. Air sungai juga terdiri dari campuran berbagai zat.

3. Mengungkapkan Hikmah Penciptaan yang Menumbuhkan Syukur

Buku teks Kimia XII banyak menjelaskan manfaat dari memahami berbagai fenomena alam bagi kehidupan sehari-hari. Sebagian dari manfaat tersebut biasanya ditunjukkan melalui berbagai hasil percobaan dari berbagai penemuan sains. Misalnya, Entilen glikol sebagai zat antibeku pada pendingin mesin mobil. Zat ini sangat membantu bagi manusia pada saat musim dingin, kendaraan miliknya masih dapat difungsikan atas bantuan zat ini. Namun, semua manfaat ini tidak ada yang dijelaskan sebagai bentuk-bentuk kebaikan Allah yang harus disyukuri oleh manusia. Padahal seorang yang beriman selalu melihat setiap kebaikan yang didapatkannya adalah nikmat Allah yang wajib disyukuri. Oleh karena itu untuk menanamkan nilai keimanan di dalam buku teks Kimia XII, penjelasan mengenai manfaat produk-produk teknologi tersebut seharusnya diikuti juga dengan dorongan untuk mensyukurinya sebagai nikmat Allah.

Gejala penurunan titik beku juga memiliki terapan praktis di antaranya adalah penurunan titik beku air. Zat antibeku (biasanya etilen glikol) yang ditambahkan ke dalam sistem pendingin mesin mobil mencegah pembekuan air radiator pada musim dingin. Penggunaan $\mathrm{CaCl} 2$ dan $\mathrm{NaCl}$ untuk menurunkan titik leleh es juga sering diterapkan, misalnya untuk menyiapkan campuran pendingin dalam pembuatan es krim (Rahayu, 2009).

Dalam paragraf di atas di jelaskan bahwa salah satu zat kimia, yaitu etilen glikol, sangat berguna bagi kehidupan manusia. Kalimat tersebut bisa disisipkan hikmah penciptaannya sehingga akan menumbuhkan rasa syukur kepada sang Maha Pencipta. Paragraf di atas dapat diubah sebagai berikut.

Segala puji bagi Allah yang telah menciptakan berbagai zat yang berguna bagi kehidupan manusia. Salah satu zat yaitu zat antibeku (biasanya etilen glikol) yang ditambahkan ke dalam sistem pendingin mesin mobil mencegah pembekuan air radiator pada musim dingin. Penggunaan $\mathrm{CaCl} 2$ dan $\mathrm{NaCl}$ untuk menurunkan titik leleh es juga sering diterapkan, misalnya untuk menyiapkan campuran pendingin dalam pembuatan es krim. Jika saja Allah tidak menghendaki zat-zat tersebut berfungsi sesuai sifat-sifatnya dan tidak menurunkan pengetahuan tentangnya kepada kita, tentunya kita tidak akan menikmati es krim yang enak.

4. Mengoreksi Konsep yang Bertentangan dengan Ajaran Islam

Boleh jadi terdapat konsep sains yang secara prinsip bertentangan dengan pandangan hidup Islam karena pelajaran sains yang diajarkan sekolah-sekolah mengacu pada pelajaran sains di Barat. Karena itu Al-Attas menegaskan bahwa dalam salah satu langkah mengislamkan sains adalah dengan mengidentifikasi dan mengoreksi konsep-konsep yang bertentangan dengan pandangan hidup Islam atau dewesternisasi (Alim, 2012). Akan tetapi, penulis belum menemukan konsep yang bertentangan dengan pandangan hidup Islam dalam buku teks Kimia XII.

5. Memasukkan Ayat al-Qur'an atau Hadits yang Relevan.

Sebagaimana telah disebutkan sebelumnya bahwa al-Qur'an dan alam keduanya merupakan ayat-ayat Allah, atau wahyu Allah, di mana keduanya memiliki kaitan yang erat. Oleh karena itu ketika seseorang menyaksikan atau mempelajari fenomena alam tertentu, 
maka alam tidak cukup dipahami sebagai sesuatu yang berdiri sendiri, melainkan terkait erat dengan Allah sebagai Pencipta dan Pemeliharanya. Al Qur'an adalah kitab petunjuk agar manusia dapat memaknai berbagai peristiwa alam sebagaimana petunjuk yang diberikan Allah. Oleh karena itu al-Qur'an (dan juga Hadits Nabawi) selain dapat menjadi rujukan dalam menerangkan teori-teori sains, juga dapat menjadi sarana menanamkan nilai-nilai keimanan (Alim, 2012).

Beberapa ayat dalam Al-Qur'an yang dapat dimasukan ke dalam materi pembahasan yaitu sebagai berikut:

a. Ayat-Ayat yang Berkaitan dengan Sifat Koligatif Larutan

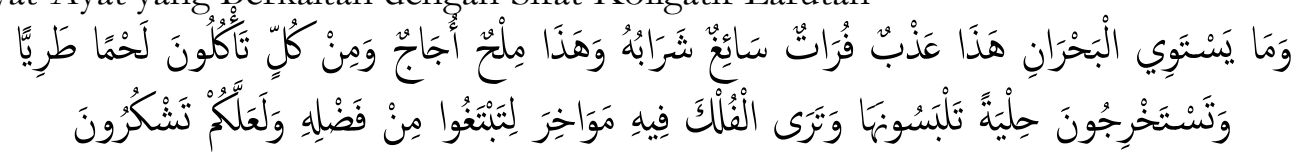

Dan tiada sama (antara) dua laut; yang ini tawar, segar, sedap diminum dan yang lain asin lagi pahit. Dan dari masing-masing laut itu kamu dapat memakan daging yang segar dan kamu dapat mengeluarkan perhiasan yang dapat kamu memakainya, dan pada masing-masingnya kamu lihat kapal-kapal berlayar membelah laut supaya kamu dapat mencari karunia-Nya dan supaya kamu bersyukur. (QS. Fathir (35): I2)

b. Ayat-Ayat yang Berkaitan dengan Reaksi Redoks dan Elektrokimia

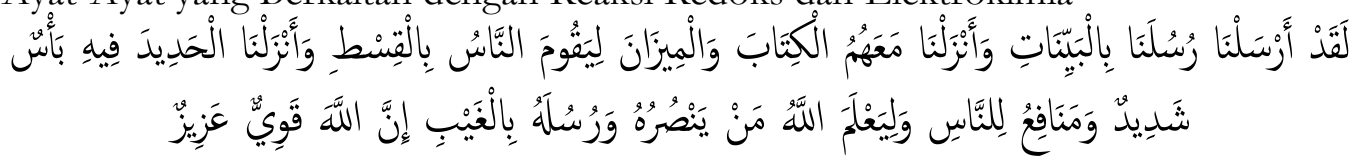

Sesungguhnya Kami telah mengutus rasul-rasul Kami dengan membawa bukti-bukti yang nyata dan telah Kami turunkan bersama mereka Al Kitab dan neraca (keadilan) supaya manusia dapat melaksanakan keadilan. Dan Kami ciptakan besi yang padanya terdapat kekuatan yang hebat dan berbagai manfaat bagi manusia, (supaya mereka mempergunakan besi itu) dan supaya Allah mengetahui siapa yang menolong (agama) Nya dan rasul-rasul-Nya padahal Allah tidak dilihatnya. Sesungguhnya Allah Maha Kuat lagi Maha Perkasa. (QS. Al-Hadid (57): 25)

c. Ayat-Ayat yang Berkaitan dengan Kimia Unsur

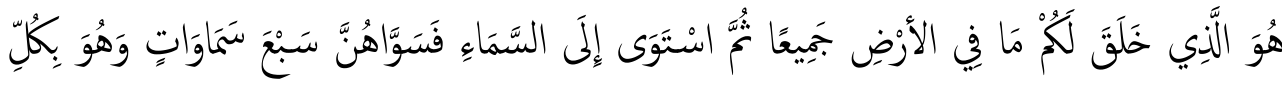

$$
\begin{aligned}
& \text { شَيْيٍْ عَليِقِ }
\end{aligned}
$$

Dia-lah Allah, yang menjadikan segala yang ada di bumi untuk kamu dan Dia berkehendak menuju langit, lalu dijadikan-Nya tujuh langit. Dan Dia Maha Mengetahui segala sesuatu. (QS. Al-Baqarah (2): 29)

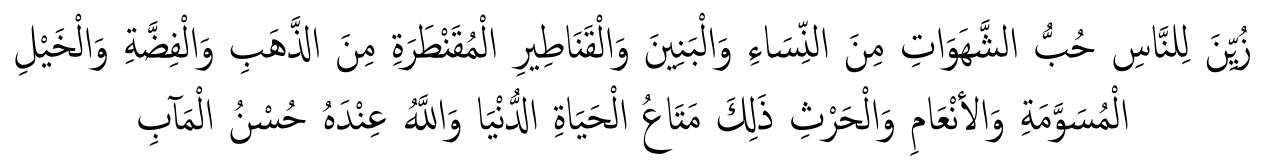

Dijadikan indah pada (pandangan) manusia kecintaan kepada apa-apa yang diingini, yaitu: wanitawanita, anak-anak, harta yang banyak dari jenis emas, perak, kuda pilihan, binatang-binatang ternak dan sawah ladang. Itulah kesenangan hidup di dunia dan di sisi Allah-lah tempat kembali yang baik (surga). (QS. Ali Imran (3): I2)

6. Memasukkan Informasi Kiprah Ilmuwan Muslim

Kebanyakan nama ilmuwan yang diangkat di dalam buku teks Kimia XII dan juga buku teks IPA dewasa ini adalah para ilmuwan Barat yang notabene bukan Muslim. Sementara itu tidak ada satu pun ilmuwan Muslim pun yang disebutkan namanya di dalam buku ini. Hal ini dapat dipahami karena hampir seluruh teori-teori sains yang dibahas di dalam buku ini 
merupakan karya-karya ilmuwan Barat, dan sebaliknya tidak ada karya ilmuwan Muslim yang dibahas dalam buku ini.

Ketiadaan nama ilmuwan Muslim dalam buku-buku sains kontemporer sebenarnya tidak mengesankan bahwa peradaban Islam tidak memiliki kontribusi apa pun terhadap pengembangan sains. Padahal yang terjadi adalah sebaliknya. Menurut Akdogan, kelahiran sains modern di Barat sebenarnya dapat dilacak sejarahnya dari peradaban Islam. Oleh karena itu Akdogan mengatakan bahwa Muslimlah yang sebenarnya menjadi perintis pertama pengembangan sains modern. Karena melemahnya kekuatan negara-negara Islam akibat konflik internal serta kekalahan negara Muslim di medan perang menghadapi tentara Kristen dan Mongol di abad ke-13, perkembangan dunia sains di dunia Muslim mulai melemah. Sementara pada saat yang sama masyarakat Barat berhasil memanfaatkan momentum kemunduran dunia Islam ini dan mengambil alih dominasi dunia Islam dalam sains .

Meskipun peradaban Islam adalah perintis sains modern, hampir tidak ada nama ilmuwan Muslim yang menghiasi buku pelajaran sains, termasuk salah satunya adalah buku teks Kimia XII ini. Semuanya adalah karya para ilmuwan Barat belaka. Ketiadaan nama ilmuwan Muslim beserta kiprahnya di dunia sains ini dapat memberikan kesan kepada siswa bahwa peradaban Islam tidak memberi sumbangan apa pun terhadap pengembangan sains. Hal ini berpotensi menghilangkan kebanggaan siswa Muslim terhadap agamanya sendiri dan juga sejarahnya. Sebaliknya di di sisi lain hal ini menumbuhkan rasa minder terhadap kebudayaan Barat. Bila hal ini dibiarkan saja, maka hal itu dapat menyebabkan hilangnya keyakinan para siswa terhadap ajaran agamanya dan sebaliknya mereka cenderung memuja peradaban Barat yang dipandang lebih unggul daripada Islam.

Untuk menanamkan nilai keimanan kepada siswa, buku teks IPA perlu juga mengangkat kontribusi tokoh-tokoh ilmuwan Muslim yang berjasa besar dalam pengembangan sains. Dalam konteks Kimia XII, nama-nama ahli kimia Muslim bisa disisipkan ke dalam kolom khusus "legenda kimia' yang berkaitan dengan materi, yang mengangkat kiprah ilmuwan muslim.

Jabir ibn Hayyan, misalnya dapat dimasukkan ke dalam pembahasan buku Kimia XII karena ia dapat menjelaskan teknik pendinginan yang dapat dipakai sebagai bagian proses penyulingannya. Beberapa hasil penyulingan berupa alkohol dimanfaatkannya untuk proses kimia dalam produksi asam, pengobatan, parfum, dan tinta untuk menulis. Ia juga telah menemukan teori-teori kimia baru tentang logam yang sangat spesifik yang telah berhasil dikembangkannya, disebarkan dengan otoritasnya sehingga meraih pengakuan internasional. Teori tersebut memandang kelas-kelas tubuh untuk pertama kalinya dari sudut pandang kimiawi, dan mencoba menjelaskan perbedaan antara substansi yang mengandung hal-hal ini, dengan mengasumsikan komposisi yang tidak umum. Logam, sebagaimana diajarkan oleh Jabir ibn Hayyan, terdiri dari sulfur dan merkuri dengan proporsi yang berbeda dan tingkat kemurnian tertentu. Terkadang, Jabir ibn Hayyan juga menambahkan unsur arsenik sebagai unsur ketiga yang paling memungkinkan.

7. Mengaitkan Materi dengan Penerapan Ajaran Islam

Disamping melalui pelajaran agama, pelajaran sains sebenarnya dapat juga dimanfaatkan untuk mengajarkan beberapa aspek syariat Islam yang terkait dengan materi pelajaran yang tengah dibahas. Pengaitan kedua hal ini diharapkan dapat menanamkan kesadaran kepada siswa untuk selalu menerapkan ajaran Islam di segala bidang kehidupannya.

Contoh pada Bab 3: Emas

Logam emas berwarna kuning dan relatif lunak. Emas merupakan logam yang paling mudah ditempa dan paling mudah memuai. Emas dapat ditempa sedemikian tipisnya. Sebagai ilustrasi, I20.000 lembar yang ditumpuk memiliki tebal tidak lebih dari I cm. Dari I g emas dapat dibuat 
kawat sepanjang 2,5 km. Logam emas disebut juga logam mulia karena emas tidak bereaksi dengan oksigen dan tidak terkorosi di udara. Emas juga tidak bereaksi dengan asam atau basa. Oleh karenanya dalam Islam, mata uang yang digunakan adalah logam mulia/emas yang berupa dinar. Dinar menjadi mata uang resmi yang digunakan di masa keemasan Islam, bahkan hingga saat ini

\section{Kesimpulan}

Dari pembahasan di atas, maka penulis dapat menyimpulkan bahwa upaya Islamisasi sains harus terus digalakan dengan cara: Pertama ialah melakukan proses pemisahan elemenelemen dan konsep-konsep kunci yang membentuk kebudayaan dan peradaban Barat. Kedua, memasukkan elemen-elemen Islam dan konsep-konsep kunci ke dalam setiap cabang ilmu pengetahuan masa kini yang relevan. Penerapan islamisasi sains dalam buku teks Kimia XII dapat dilakukan dengan langkah-langkah sebagai berikut: pertama, memberikan pengantar yang berisikan nasihat-nasihat Islam. Kedua, menyisipkan ungkapan kemahakuasaan Allah. Ketiga, mengungkapkan hikmah penciptaan alam yang menumbuhkan syukur. Keempat, mengoreksi konsep yang bertentangan dengan ajaran Islam. Kelima, memasukkan ayat AlQur'an atau hadits yang relevan. Keenam, memasukkan informasi kiprah ilmuwan muslim dan terakhir mengaitkan materi dengan penerapan ajaran Islam.

\section{Daftar Pustaka}

al-Faruqi, I. R. (1984). Islamisasi Pengetahuan. Bandung: Penerbit Pustaka.

Alim, A. (2012). Studi Islam VI: Islamisasi Sains \& Teknologi: Meluruskan Paradigma Sains Sekuler, Menuju Sains yang Berbasis pada Ajaran Islam. Bogor: Pustaka Al Bustan.

Armas, A., \& Kania. (2013). Sekularisasi Ilmu, dalam buku Filsafat Ilmu Perspektif Islam dan Barat. Jakarta: Gema Insani.

Bakar, O. (2008). Taubid dan Sains: Perspektif Islam tentang Agama dan Sains. Bandung: Pustaka Hidayah.

Fauzan, S. bin. (2016, September 28). Renungkanlah Ayat-Ayat Allah Azza wa Jalla. Retrieved from Almanhaj.or.id website: https://almanhaj.or.id/3533- renungkanlah-ayat-ayatallah-azza-wa-jalla.html

Handrianto, B. (2010). Lima Konsep Islamisasi Sains, Jakarta. Islamia: Jurnal Pemikiran Islam Republika.

Harnanto, A., \& Ruminten. (2009). Kimia 3: Untuk SMA/MA Kelas XII. Jakarta: Pusat Perbukuan Departemen Pendidikan Nasional.

Husaini, A., \& al. (2013). Filsafat Ilmu Perspektif Islam dan Barat. Jakarta: Gema Insani.

Muslich, M. (2016). Text Book Writing: Dasar-Dasar Pemahaman, Penulisan, dan Pemakaian Buku Teks. Ar-Ruzz Media.

Rahayu, I. (2009). Praktis Belajar Kimia: Untuk Kelas X Sekolah Menengah Atas / Madrasah Aliyah. Jakarta: Pusat Perbukuan, Departemen Pendidikan Nasional.

Supraha, W. (2018). Pemikiran George Sarton dan Panduan Islamisasi Sains. Depok: Yayasan Adab Insan Mulia.

Suwardi, S., \& Widiasih, T. E. (2009). Panduan Pembelajaran Kimia XII Untuk SMA \& MA. Jakarta: Pusat Perbukuan Departemen Pendidikan Nasional.

Zarman, W. (2012). Studi Pengembangan Buku Teks Ilmu Pengetahuan Alam Sekolah Menengah Pertama Berbasis Nilai Keimanan. Bogor: Universitas Ibn Khaldun. 